\title{
NOTES ON THE BIOLOGY OF \\ POLISTES CARNIFEX (HYMENOPTERA, VESPIDAE) IN COSTA RICA AND COLOMBIA*
}

\author{
By Mary L. CORN \\ The Biological Laboratories, Harvard University \\ Cambridge, Massachusetts 02138
}

According to Bequaert (1936), Polistes carnifex (Fabricius) is the largest representative of the genus in the Neotropics. Its distribution extends from northern Argentina to Mexico. Little is known of its biology or behavior. Bertoni (I9II) described a nest from Paraguay; Bequaert ( 1936) named new color varieties; Reid ( I942) studied the developmental stages; and Weyrauch (1942) described a nest of $P$. carnifex var. boliviensis in Peru. These authors noted that carnifex builds a pendant, horizontal, open-faced nest with a single, central pedicel. The pedicel is covered with a tough, dark, gelatin-like material.

$\mathrm{My}$ observations were conducted in 2 areas. Site $\mathrm{A}$ was near Palo Verde, Guanacaste Province, Costa Rica. Six nests were taken there in July, I97I, in the rainy season. Site B was in the vicinity of Cali, Colombia, where I observed an individual nest for over 30 hours over a 2 week period at the close of the dry season in January, 1972.

At Site $\mathrm{A}$ the six nests were among dozens of carnifex nests in various low, shrubby, thorn bearing trees, some of which were legumes, though several species were represented. The trees grew along the edge of a large seasonal swamp. Most of the nests were associated with (that is, in the same tree, less than $\mathrm{I} \mathrm{m}$ from) large nests of a polybiine, probably Polybia sp. Rarely, a third wasp, Mischocyttarus sp. nested in the same cluster. Windsor (1972) has found an association of Polybia and Mischocyttarus in the same province, but carnifex was rarely found in it, though the other two species are possibly the same. At site $A$, the nests of all 3 species sometimes occurred within I $\mathrm{m}$ of each other. Since many trees contained no nests of carnifex at all, the distribution seemed non-random. The association of carnifex with other species of social wasps has not been reported elsewhere.

$P$. carnifex was much less aggressive than its size might suggest. Entire nests were captured safely at night. Only two adults were

*Manuscript received by the editor May 8, 1972. 
Table 1

Adult populations of six nests of Polistes carnifex.

\begin{tabular}{|c|c|c|c|c|c|c|}
\hline Nest & $\begin{array}{c}\text { Associated } \\
\text { with Polybia }\end{array}$ & $\begin{array}{l}\text { Total Adult } \\
\text { Population }\end{array}$ & Male & $\begin{array}{c}\text { Numbe } \\
\text { in Each } \\
\text { Class } \\
\text { A }\end{array}$ & $\begin{array}{l}\text { of } \\
\text { Rep } \\
\text { (see } \\
\text { B }\end{array}$ & $\begin{array}{l}\text { Females } \\
\text { roductive } \\
\text { Text)* } \\
\text { C }\end{array}$ \\
\hline 2 & + & 13 & 1 & 0 & 1 & 9 \\
\hline $3 \mathrm{~A}$ & + & 13 & 0 & 4 & 1 & 6 \\
\hline 4 & + & $8 * *$ & 2 & 0 & 1 & 3 \\
\hline B6a & - & 8 & 0 & 0 & 1 & 5 \\
\hline B6b & - & 4 & 0 & 0 & 0 & 2 \\
\hline B7 & - & 8 & 0 & 1 & 0 & 5 \\
\hline
\end{tabular}

* The sum of males and females listed here does not equal the total population because two specimens were saved for identification from each nest.

**Two specimens escaped from this nest; therefore, only six animals were examined.

known to have escaped and both of these were from nest number 4 . Three of the nests were associated with polybiine nests; 3 were not.

The maximum nest size was about $9 \mathrm{~cm}$ in diameter. In one nest, cells from which at least one emergence had occurred had an average length of $27.8 \mathrm{~mm}(\mathrm{~s}=2.770 \mathrm{~mm})$. In all of the nests, the central cells were in at least their second cycle of brood, that is, the age of the nests was greater than $I$ according to the terminology of Richards and Richards (I95I).

The total adult population on these nests ranged from 4 to 13 (Table I). All but 2 of the adults from each nest were dissected. The remainder were saved for identification and have been deposited in the Harvard Museum of Comparative Zoology and the British Museum of Natural History. The dissected females were divided into the following 3 categories: (A) those females with 4 or more full-sized eggs; (B) those females with I-3 full-sized eggs; and (C) those females with no full-sized eggs. The last category included 5 females with very small eggs. Table I shows that not all nests included a female with well developed ovaries. Possibly laying females were among those saved for identification.

Table 2 shows the number of eggs, larvae, capped cells (prepupae and pupae), and empty cells in each nest. There was no clear evidence of parasitism in any of the nests. In 3 cells, there was an additional egg, but these eggs seemed to be carnifex eggs, rather than parasites. Ten arbitrarily selected larvae were dissected. They showed no evidence of parasitism.

Unfortunately, time was too short for behavioral studies at this site. However, it is clear that there are no obvious differences be- 


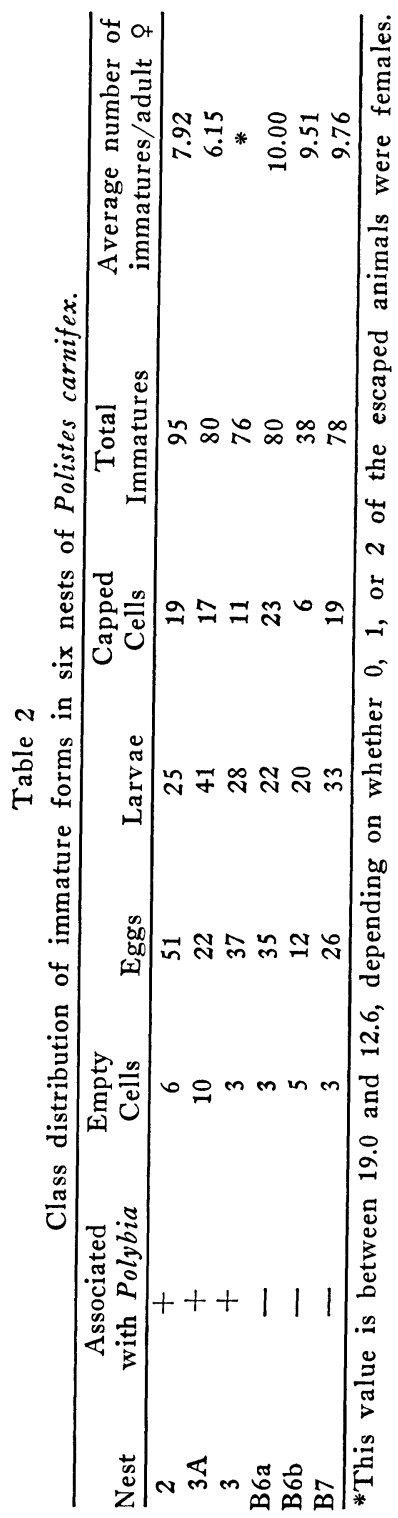


tween associated and nonassociated nests in the incidence of parasitism, the size of the adult population, or the average number of immatures per adult female.

The nest at site $B$ was under the eaves of a tin roof of an abandoned house. There were no other wasps' nests nearby. The nest structure was similar to that of the Costa Rican nests, except that the closed cells had flat recessed caps rather than convex caps as in Costa Rica. These cells average about $30.0 \mathrm{~mm}$ in overall length ( $\mathrm{s}=2.030 \mathrm{~mm}$ ), a mean which was significantly larger than the mean of the Costa Rican nests (Fisher-Behrens test, $\mathrm{d}=2.885 \mathrm{I}$, $\Theta=73^{\circ}, v_{1}, v_{2}=35$, I0, $\left.\mathrm{p}<0.05\right)$.

Most of the observations on this nest were made during hours of bright sunshine, when the wasps forage. The 2 adults present on the nest initially were marked at the beginning of the study. Others were marked within a day or 2 after emergence. (See Table 3.)

The number of cells (28) remained constant throughout the I 7 days of observation. Only one cell, a peripheral one, was observed being enlarged. The queen brought in a ball of freshly macerated pulp and applied it herself, after unsuccessful attempts to divide it among her nestmates. Her behavior in applying the pulp was the same as that described by Eberhard (1969) in $P$. fuscatus. The queen applied the load with her mandibles, while holding her foretarsi on either side of the wall under construction. As she worked she moved her antennae in circles beside her head, touching the opposite, parallel wall as she did so. According to Eberhard, it is the antennal contact with the opposite cell walls which enables the

Table 3

Seventeen day history of a five membered colony of Polistes carnifex near Cali, Colombia. The solid line indicates presence on the nest. The dashed line indicates periods of foraging. Female No. 1 had developed ovaries.

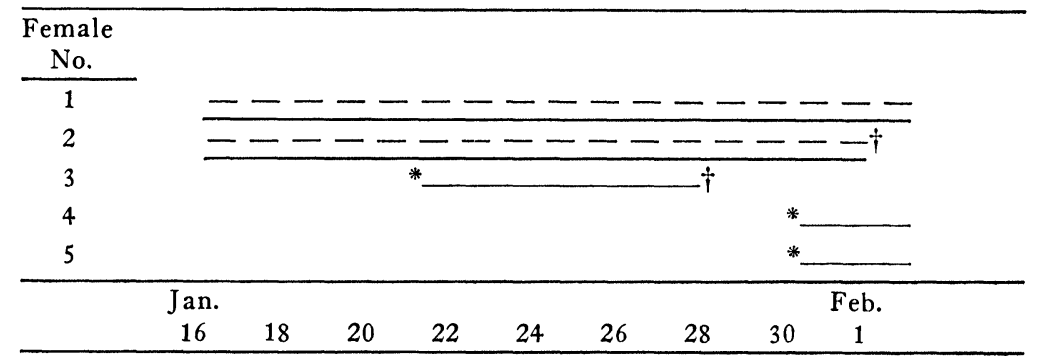

*emerged

$\dagger$ died or disappeared 
wasp to form straight sides on the inner walls of the cell. Conversely, it is the lack of antennal contact along the outer margin of a peripheral cell which causes those walls to be rounded.

Dominance interactions between females were never very aggressive. The highest ranking wasp on the nest invariably received food first from the returning forager. The higher ranking wasp generally held its body farther from the substrate than the subordinate during the feeding (see Fig. I). The solicitor tilted its head to one side during the exchange and antennated the face of the donor. Occasionally, the solicitor, and especially the queen, held onto the donor and prevented her escape.

Dominance interactions unrelated to food exchange were rare. In one of the few observed, the queen, apparently unprovoked, moved toward the third ranking individual and, holding her with her prothoracic legs, began to bite the subordinate about the mandibles, eyes, neck, thorax and wings. The subordinate held her body very close to the nest. When she tried to back away, the queen held her and began biting more vigorously. When the attack ceased, the subordinate retreated to a position on top of the nest, while the queen returned to the face of the nest.

When I disturbed the nest severely, the wasps showed typical threat behavior. At low intensities, the wasp faced the disturbance and raised and spread its wings. At higher intensities, the aroused individual buzzed its wings in short bursts. It was this action which seemed to arouse the nestmates. If the disturbance was very intense (as when I was marking the wasps) the females would fly off the nest and circle it a few feet away. After such intense disturbances, buzzing threat displays continued for up to ro minutes.

Foragers about to leave the nest held themselves erect on the nest, buzzed their wings loudly, paused for a moment, and then took off. A brief orientation flight generally followed. The returning foragers sometimes made a number of approaches before alighting on the nest. Occasionally the wasp landed on a rafter adjacent to the nest, groomed for a moment, and then took off and landed on the nest immediately. The queen herself made 5 of the 29 foraging trips seen in this study. On the 29 trips, the foragers brought 25 loads of nectar, 3 loads of macerated greenish-gray prey, and I load of pulp.

The returning forager fed the highest ranking resident first and then she and the solicitor fed the larvae (see Fig. 2). The wasps stuck their heads into the cells and then rapidly antennated the opposite wall of the cell. The sound produced by the antennae striking 


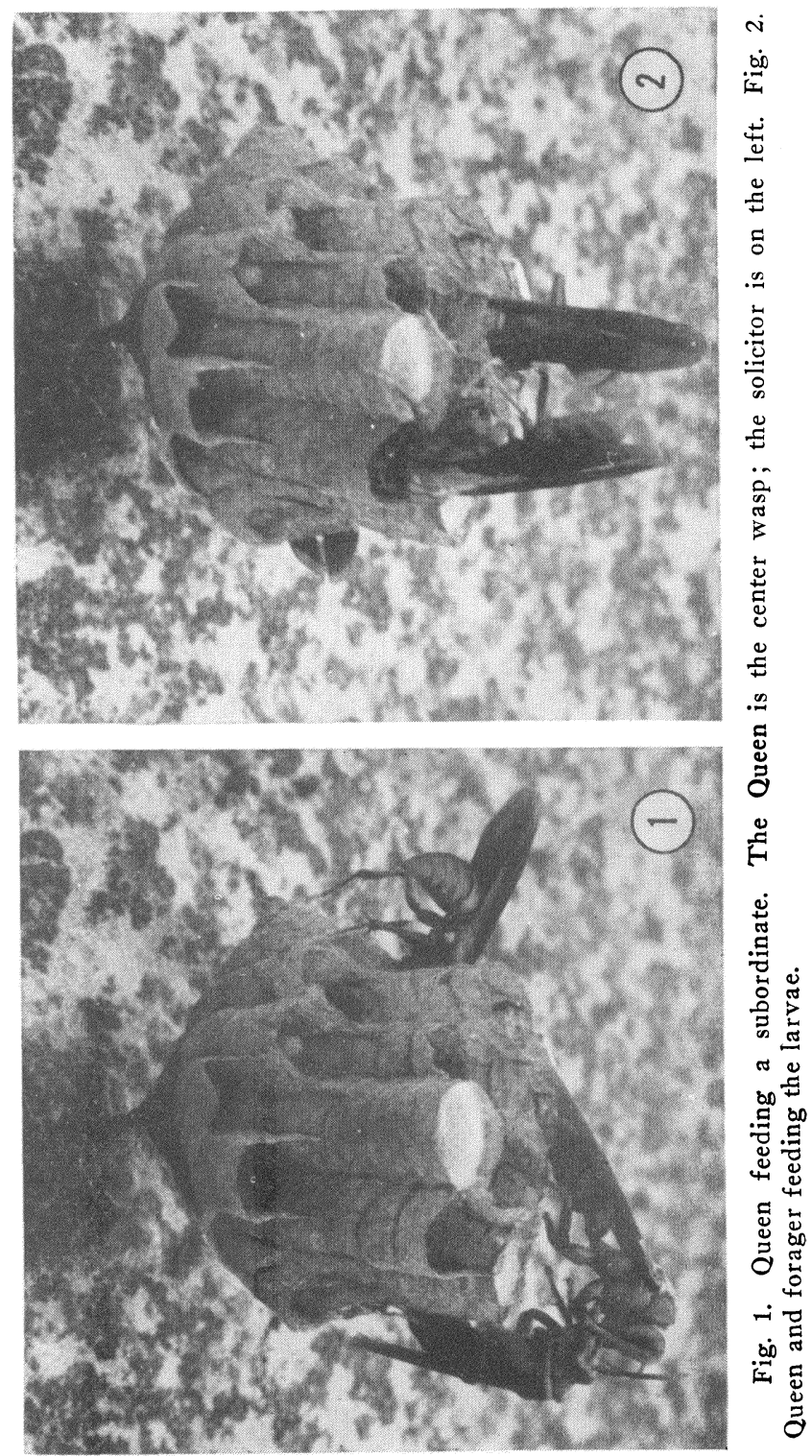


the cell was easily audible at a distance of $\mathrm{I} \mathrm{m}$ from the nest. Possibly this behavior alerted the larvae to the food offering. After feeding 2 or 3 larvae, the forager usually groomed briefly and then took off. The entire exchange sometimes took as little as 2 minutes. When a third wasp was present on the nest, it sometimes tried to steal food during the exchange. In one case, when the third wasp managed to obtain a large amount of nectar, the exchange ended with the donor biting the intruder.

As the queen moved about the nest, she often dragged her abdomen across the face of the nest, and moved it slightly from side to side in the process. Other wasps showed the same behavior but less consistently. The queen and the second ranking female both showed a peculiar behavior of rubbing their abdomens over the pedicel of the nest; the queen twice and the second ranking female 4 times. A similar behavior was reported by Jeanne (1970) in Mischocyttarus drewseni. He showed that wasps in that species were depositing a substance which is repellent to ants.

On only one occasion was the queen observed eating an egg. The process took about 3 minutes. She did not lay another egg in the cell. In fact, I did not see any of the wasps ovipositing during all of my observations, though nest records show that they must have laid at least 4 eggs during the $I 7$ days. At the end of the observation period, the queen was dissected and found to contain 4 ripe eggs and a full spermatheca.

\section{Conclusion}

The behavioral repertoire of this wasp is very similar to that of $P$. canadensis as reported by Eberhard (1969). The size and gentleness of this wasp make it very suitable for behavioral observations. The association of $P$. carnifex with other social wasps has not been reported outside of Costa Rica. Data on the nesting success in associated and non-associated nests are needed to determine what advantage, if any, Polistes carnifex receives or confers in this association.

\section{ACKNOWLEDGements}

Part of this study was a field project in the Tropical Ecology course (197I) of the Organization for Tropical Studies. I am grateful to Peter Becker, Valerie Dryer, Doug Gill, Julie Multer, and $\mathrm{Al}$ Muth, who made heroic efforts collecting the nests in Costa 
Rica. I am also very grateful to Drs. William and Mary Jane Eberhard for their hospitality during my stay in Colombia and for their valuable discussion and assistance in these observations. $M$. J. W. Eberhard dissected the queen from Colombia. Prof. O. W. Richards kindly identified the specimens of Polistes. This research has received partial support from NSF Grant No. GB279I I R. C. Rollins, Harvard University, principal investigator. Roger Swain, Robert Silberglied and Dr. H. E. Evans provided helpful comments on the manuscript. This paper is published with the aid of a grant from the Museum of Comparative Zoology at Harvard University.

\section{Literature Cited}

BEQUAERT, J.

1936. Color variation in the South American social wasp, Polistes carnifex (Fabricius) (Hymenoptera, Vespidae). Rev. Entomol.

Bertoni, A. (Rio de Janeiro), 6: 376-383.

1911. Contribution a la biologia de las avispas y abejas del Paraguay. Anal. Mus. Nac. Bs. As. Ser. 3. 15: 97-146.

EBERHARD, M. J. W.

1969. The social biology of polistine wasps. Misc. Publ. Mus. Zool. U. Mich. No. 140. 101 pp.

JEANNE, R. L.

1970. Chemical defense of brood by a social wasp. Science, 168:14651466.

REID, J. A.

1942. On the classification of the larvae of the Vespidae (Hymenoptera). Trans. Roy. Entomol. Soc. Lond., 92: 285-331.

RICHARDS, O.W. and M. J. RichaRdS

1951. Observations on the social wasps of South America (Hymenoptera, Vespidae). Trans. Roy. Entomol. Soc. Lond., 102: 1-170.

WEYRAUCH, W.

1942. Nidos de insectos peruanos en el Museo de Historia Natural. WINDSOR, D. Bol. Mus. Hist. Nat. (Lima), 6: 52-66.

1972. Nesting association between two Neotropical polybiine wasps. Biotropica (in press). 

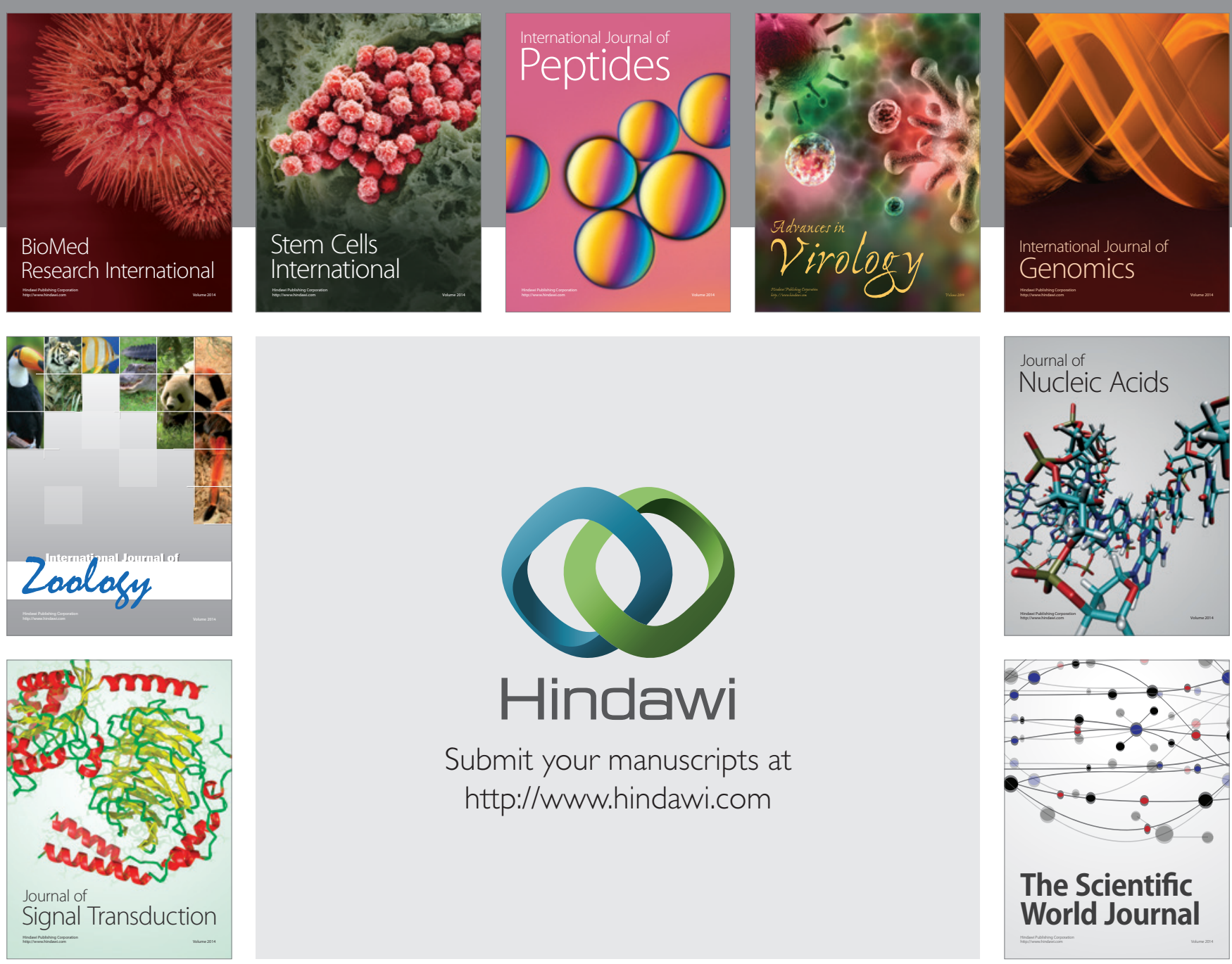

Submit your manuscripts at

http://www.hindawi.com
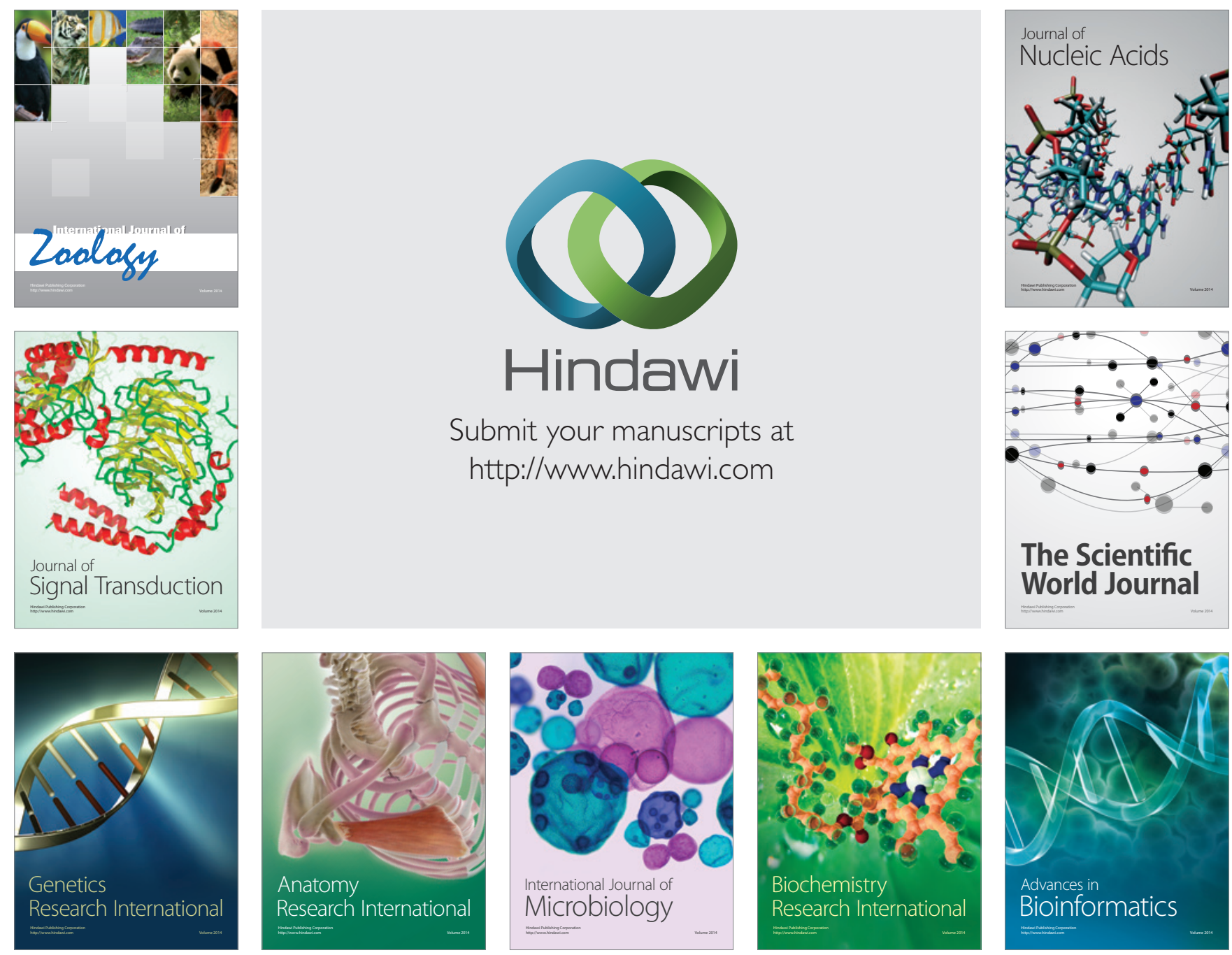

The Scientific World Journal
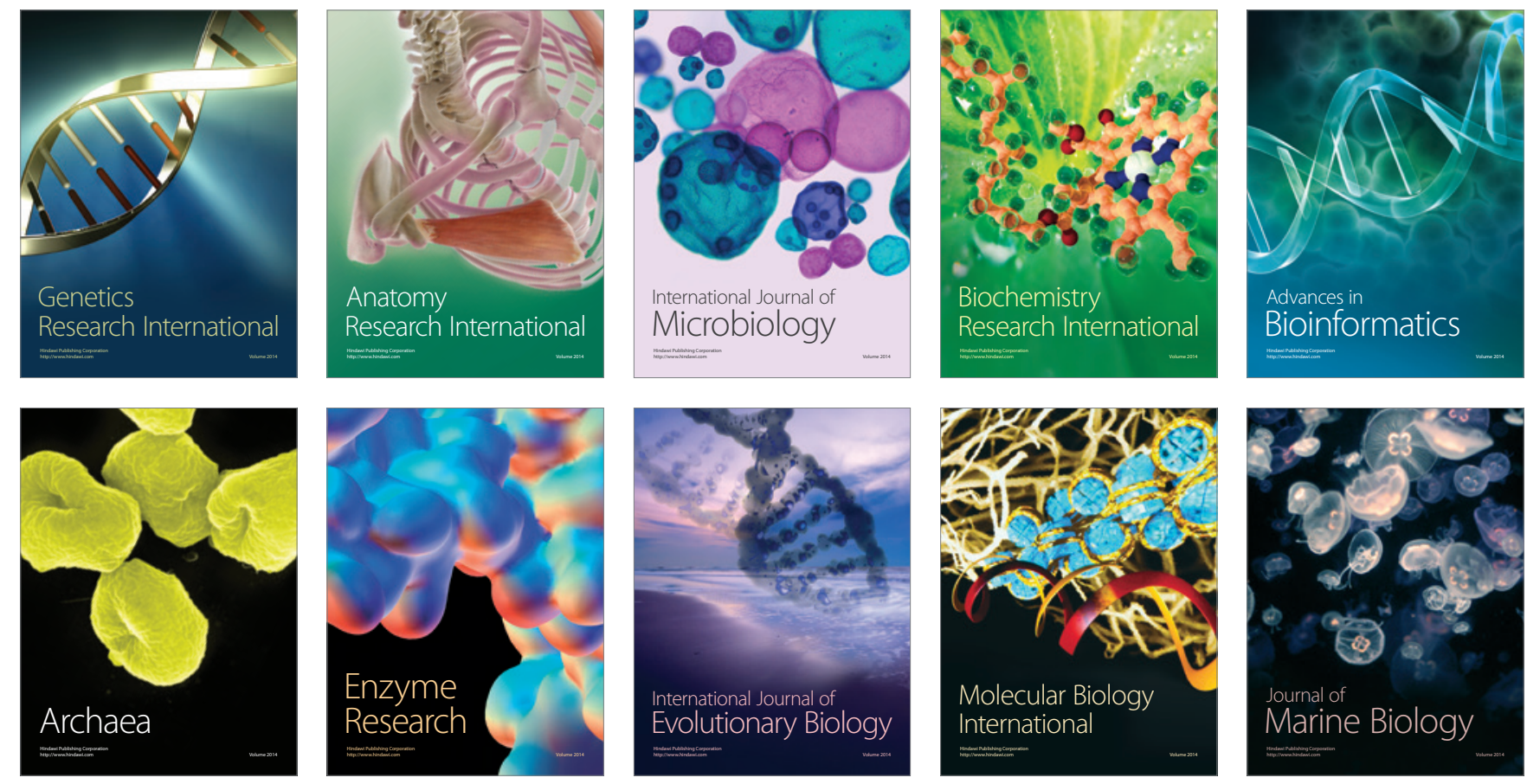